\title{
The AMP-activated protein kinase activator, 5-aminoimidazole- 4-carboxamide-1-b-D-ribonucleoside, regulates lactate production in rat Sertoli cells
}

\author{
María Noel Galardo ${ }^{1,2}$, María Fernanda Riera ${ }^{1}$, Eliana Herminia Pellizzari' ${ }^{1}$, \\ Selva Beatriz Cigorraga ${ }^{1}$ and Silvina Beatriz Meroni ${ }^{1}$ \\ ${ }^{1}$ Centro de Investigaciones Endocrinológicas (CEDIE), Hospital de Niños Ricardo Gutiérrez, Gallo 1330, 1425 Buenos Aires, Argentina \\ ${ }^{2}$ Departamento de Bioquímica Humana, Facultad de Medicina, Universidad de Buenos Aires, Paraguay 2155 th floor, 1121 Buenos Aires, Argentina \\ (Correspondence should be addressed to S B Meroni; Email: smeroni@ cedie.org.ar)
}

\begin{abstract}
The aim of the present study was to investigate whether the AMP-activated protein kinase (AMPK), a key regulator of cellular energy homeostasis, is present in Sertoli cells and whether its activation by 5-aminoimidazole-4-carboxamide-1-b-Dribonucleoside (AICAR) results in the regulation of cell metabolism to ensure lactate supply for germ cell development. Sertoli cell cultures from 20-day-old rats were used. Western blot analysis for the $\alpha$-subunit of AMPK showed that high levels of AMPK are present in Sertoli cells. Treatment of the cultures with AICAR resulted in a dose- and time-dependent increase of PAMPK levels indicating activation of the enzyme. A possible effect of AICAR on Sertoli cell lactate production was then analyzed. A dose- and time-dependent increment in lactate secretion was observed. The participation of AMPK activation in different biochemical processes that may be implicated in the regulation of lactate production was also analyzed. AICAR stimulated glucose uptake in a dose- and time-dependent manner. Additionally, AICAR increased the glucose transporter 1 (GLUT1) and decreased the glucose transporter 3 (GLUT3) mRNA levels. As for the role of AMPK in the regulation of the monocarboxylate transporters 1 and 4 (MCT1 and MCT4), it has been observed that AICAR treatment decreased MCT1 and increased MCT4 mRNA levels. In summary, the results presented herein show that AMPK is present in Sertoli cells and that its activation by AICAR increases lactate production as a result, at least in part, of a) an increase in glucose uptake, b) an increase in GLUT1 expression, and c) a decrease in MCT1 and an increase in MCT4 levels. Altogether, these results suggest an important role of AMPK in modulating the nutritional function of Sertoli cells.
\end{abstract}

Journal of Molecular Endocrinology (2007) 39, 279-288

\section{Introduction}

The process of spermatogenesis and consequently male fertility are dependent upon the somatic cells that are present in the testis. On the one hand, Leydig cells are essential because of androgen production. On the other hand, Sertoli cells are absolutely necessary in order to provide an adequate and protected environment within the seminiferous tubules. Germ cells situated beyond the blood testis barrier need to rely on Sertoli cell production of factors that fuel germ cell metabolism. In this context, lactate produced by Sertoli cells is delivered to and used by germ cells as an energy substrate. The importance of lactate for normal spermatogenesis was highlighted in a report showing that spermatogenesis in adult cryptorchid testis is improved by intratesticular infusion of lactate (Courtens \& Ploen 1999). Glucose transport mediated by glucose transporters (GLUTs), lactate dehydrogenase $(\mathrm{LDH})$ isoenzyme system reversibly catalyzing the interconversion of pyruvate in lactate, and lactate transport across the plasma membrane mediated by monocarboxylate transporters (MCTs) are prime targets to be regulated for achieving an increase in lactate offer to germ cells.

Cells change their metabolism by activating specific signal transduction pathways. The AMP-activated protein kinase (AMPK) is a key regulator of cellular energy homeostasis (Hardie 2003). It is a trimeric enzyme consisting of a catalytic subunit $\alpha$, and two regulatory subunits $\beta$ and $\gamma$ which is activated by an increase in the AMP:ATP ratio. Activation of AMPK involves several mechanisms. Firstly, AMP activates (5-fold) AMPK by direct allosteric regulation of the enzyme. Secondly, binding of AMP induces a conformational change that makes the protein a better substrate for the phosphorylation of the $\alpha$-subunit at a specific Threonine residue, Thr 172, by the upstream kinase LKB1. Phosphorylation by LKB1 constitutes the primary mechanism for the stimulation of AMPK activity (50- to 100-fold). Thirdly, the conformational modification of the protein induced by AMP binding also provokes a decrease in dephosphorylation by phosphatases and contributes to a 
sustained activation of the enzyme (Hardie 2004). Altogether, these mechanisms make the AMPK system ultrasensitive to energy changes, an important fact for the ability of the enzyme to maintain the energy status of the cell within narrow limits. The adenosine analog, 5-aminoimidazole-4-carboxamide-1-b-D-ribonucleoside (AICAR), is a potent activator of AMPK system (Corton et al. 1995). AICAR has been extremely useful to analyze the metabolic effects resulting from AMPK activation in skeletal muscle, adipose tissue, and liver (Xi et al. 2001, Fryer et al. 2002, Gaidhu et al. 2006).

Several reviews have dealt with the downstream targets and processes regulated by AMPK (Hardie \& Pan 2002, Hardie 2005, Hardie \& Sakamoto 2006). In general, activation of AMPK downregulates biosynthetic pathways such as fatty acid and cholesterol biosynthesis, yet switches on catabolic pathways that generate ATP, such as fatty acid oxidation, glucose uptake, and glycolysis. AMPK regulates the abovementioned phenomena not only through direct phosphorylation of metabolic enzymes, but also through effects on the expression of genes that are important to these metabolic pathways.

Recently, different subunits of AMPK have been demonstrated to be present in the testis (Cheung et al. 2000). However, no studies are available on the downstream metabolic processes that may be activated in this organ. The aim of the present study was to investigate whether AMPK is present in Sertoli cells and its activation by AICAR results in the regulation of cell metabolism in order to ensure the supply of lactate for germ cell development.

\section{Materials and methods}

\section{Materials}

Tissue culture media was purchased from GIBCO BRL (Life Technologies Ltd). AICAR was purchased from Calbiochem. [2,6-3H]-2-deoxy-D-glucose (2-DOG) was purchased from NEN (Boston, MA, USA). All other drugs and reagents were purchased from Sigma Chemical Co.

\section{Sertoli cell isolation and culture}

Sertoli cells from 20-day-old Sprague-Dawley rats were isolated as previously described (Meroni et al. 2002). Briefly, decapsulated testes were digested with $0 \cdot 1 \%$ collagenase and $0.006 \%$ soybean trypsin inhibitor in Hanks' balanced salt solution for $5 \mathrm{~min}$ at room temperature. Seminiferous tubules were saved, cut, and submitted to $1 \mathrm{M}$ glycine-2 mM EDTA ( $\mathrm{pH} 7 \cdot 4$ ) treatment to remove peritubular cells. The washed tubular pellet was then digested again with collagenase for $10 \mathrm{~min}$ at room temperature to remove germinal cells. The Sertoli cell suspension, collected by sedimentation, was resuspended in culture medium which consisted of modified Eagle's medium, supplemented with $20 \mathrm{mM}$ HEPES, $100 \mathrm{IU} / \mathrm{ml}$ penicillin, $2.5 \mu \mathrm{g} / \mathrm{ml}$ amphotericin $\mathrm{B}, 1.2 \mathrm{mg} / \mathrm{ml}$ sodium bicarbonate, $10 \mu \mathrm{g} / \mathrm{ml}$ transferrin, $5 \mu \mathrm{g} / \mathrm{ml}$ insulin, $5 \mu \mathrm{g} / \mathrm{ml}$ vitamin $\mathrm{E}$, and $4 \mathrm{ng} / \mathrm{ml}$ hydrocortisone. Sertoli cells were cultured in $25 \mathrm{~cm}^{2}$ flask, 6- or 24-multiwell plates ( $\left.5 \mu \mathrm{g} \mathrm{DNA} / \mathrm{cm}^{2}\right)$ at $34^{\circ} \mathrm{C}$ in a mixture of $5 \% \mathrm{CO}_{2}: 95 \%$ air.

No myoid cell contamination was revealed in the cultures when an immunoperoxidase technique was applied to Sertoli cell cultures using a specific antiserum to smooth muscle $\alpha$ actin. Remaining cell contaminants were of germ cell origin and this contamination was below $5 \%$ after $48 \mathrm{~h}$ in culture as examined by phase contrast microscopy.

\section{Culture conditions}

Sertoli cells were allowed to attach for $48 \mathrm{~h}$ in the presence of insulin and medium was replaced at this time with fresh medium without insulin. Stimulation with AICAR was performed with variable doses and for variable periods of time. The conditioned media and the cells pretreated for $48 \mathrm{~h}$ with variable doses of AICAR $(0 \cdot 3,0 \cdot 6$, and $1 \mathrm{mM}$ ) harvested on day 5 were used to evaluate dosedependent regulation of lactate and $\mathrm{LDH}$ activity respectively. The 12-, 24-, and 48-h conditioned media of cells pretreated with $1 \mathrm{mM}$ AICAR harvested on day 5 were used to evaluate time-dependent regulation of lactate production. Cells incubated for 12-, 24-, and 48-h with $1 \mathrm{mM}$ AICAR were used to evaluate timedependent regulation of LDH activity and GLUT1, GLUT3, MCT1, MCT4, and LDHA mRNA levels. For 2-DOG uptake studies, cells cultured for 4 days under basal conditions and pretreated for 1,2 , or $4 \mathrm{~h}$ with $1 \mathrm{mM}$ AICAR or for $2 \mathrm{~h}$ with $0 \cdot 3,0 \cdot 6$, and $1 \mathrm{mM}$ AICAR were used.

\section{Western blot analysis}

Testicular homogenates were obtained from 20-day-old rats. Two testes were weighed, decapsulated, and homogenized with six gentle strokes of a glass-Teflon pestle homogenizer in $8 \mathrm{ml}$ PBS containing $80 \mu \mathrm{l}$ a protease inhibitor cocktail (P-8340, Sigma-Aldrich) and $2 \mathrm{mM}$ phenylmethylsulfonylfluoride (PMSF) per gram of tissue. The homogenate was centrifuged at $200 \mathrm{~g}$ for $2 \mathrm{~min}$ to eliminate undisrupted tissue. The supernatant was used for electrophoretic studies.

Sertoli cells cultured in 6-multiwell plates were washed once with PBS at room temperature. Then, $200 \mu$ l PBS containing $2 \mu \mathrm{l}$ protease inhibitor cocktail and $2 \mathrm{mM}$ PMSF were added to each well. Cells were then placed on ice and disrupted by ultrasonic irradiation. 
Protein content in testis homogenates and Sertoli cell lysates was determined by Lowry's assay (Lowry et al. 1951). For western blot analysis, $2 \times$ Laemmli buffer $(4 \% \mathrm{w} / \mathrm{v}$ SDS, $20 \% \mathrm{v} / \mathrm{v}$ glycerol, $10 \% \mathrm{v} / \mathrm{v}$ 2-mercaptoethanol, $0 \cdot 004 \% \mathrm{w} / \mathrm{v}$ bromophenol blue, and $0 \cdot 125 \mathrm{M}$ Tris-HCl, pH 6.8) was added and thoroughly mixed (Laemmli 1970). Samples were immersed in a boiling water bath for 5 min and then immediately settled on ice. In each lane, $30 \mu \mathrm{g}$ protein aliquots were seeded. A biotinylated protein marker provided by Cell Signaling was also run. Proteins were resolved in $10 \%$ SDS-PAGE (10\% acrylamide/ bisacrylamide for the resolving gel and $4.3 \%$ acrylamide/bisacrylamide for the stacking gel) in a Mini Protean 3 Cell (Bio-Rad). After SDS-PAGE, gels were equilibrated in transfer buffer for $10 \mathrm{~min}$ and electrotransferred at $100 \mathrm{~V}$ for $60 \mathrm{~min}$ onto polyvinylidene difluoride membranes (Hybond-P, Amersham Pharmacia Biotech) using mini trans-blot cell (Bio-Rad). Membranes were probed with commercial antibodies for PhosphoAMPK- $\alpha$ (Thr172) and AMPK- $\alpha$ (New England Biolabs Inc., Beverley, MA, USA) which allow specific recognition of phosphorylated-AMPK (P-AMPK) and total-AMPK (T-AMPK) protein respectively, and for $\beta$-tubulin (Sigma Chemical Co). The intensities of autoradiographic bands were estimated by densitometric scanning using $\mathrm{NIH}$ Image (Scion Corporation, Frederick, MD, USA) software.

\section{Northern blot analysis}

Total RNA from decapsulated 20-day-old rat testis was prepared. Extraction was performed using TRI reagent according to the manufacturer's recomendations. RNA from Sertoli cells cultured in $25 \mathrm{~cm}^{2}$ tissue culture flasks was obtained by the guanidinium isothiocyanate method (Chomczynski \& Sacchi 1987). The amount of RNA was estimated by determining absorbance at $260 \mathrm{~nm}$. For northern blot analysis, $20 \mu \mathrm{g}$ total RNA was electrophoresed on a $1 \%$ agarose- $10 \%$ formaldehyde gel. After migration, RNAs were transferred to Hybond-N nylon membrane (Amersham Pharmacia Biotech) by capillary transfer with $20 \times \mathrm{SSC}(20 \times$ stock solution: $3 \mathrm{M} \mathrm{NaCl}$ and $0.3 \mathrm{M}$ sodium citrate, $\mathrm{pH} 7 \cdot 4$ ) and fixed with u.v. Stratalinker (Stratagene Cloning Systems, La Jolla, CA, USA). cDNA probes (rat GLUT1 2.6 kb insert, EcoRI; mouse GLUT3 0.6 kb insert, EcoRI-HindIII; rat MCT1 $1.9 \mathrm{~kb}$ insert, PstI-EcoRI; rat MCT4 $1.7 \mathrm{~kb}$ insert, HindIII-BamHI; rat LDH-A $3^{\prime}$ UTR $0.4 \mathrm{~kb}$ insert, Pst I-Bgl II and 18S oligonucleotide) were labeled with $\left[\alpha-{ }^{32} \mathrm{P}\right]$ deoxy-CTP (Amersham Pharmacia Biotech) using a random-primed labeling kit (Prime-a-Gene Labeling System, Promega Corporation). Blots were prehybridized for $5 \mathrm{~h}$ at $42{ }^{\circ} \mathrm{C}$ in $50 \%$ formamide, $\mathrm{NaCl} / \mathrm{Pi} / \mathrm{EDTA}(0.75 \mathrm{M} \mathrm{NaCl}, 20 \mathrm{mM}$ sodium phosphate $(\mathrm{pH} 7 \cdot 5)$ and $1 \mathrm{mM}$ EDTA), $5 \times$ Denhart's solution, $10 \%$ dextran sulfate, $0.5 \%$ SDS, and $100 \mu \mathrm{g}$ / $\mathrm{ml}$ herring sperm DNA. Hybridization was then performed overnight at $42{ }^{\circ} \mathrm{C}$ in the same hybridization buffer containing $1-4 \times 10^{6}$ c.p.m./ml ${ }^{32}$ P-labeled probe. Membranes were washed utilizing different astringency conditions depending on the probe utilized. Membranes were exposed to Kodak X-Omat $\mathrm{S}$ films (Eastman Kodak) software. The $18 \mathrm{~S}$ signal was used to standardize mRNA contents.

\section{Measurement of 2-DOG}

Glucose transport was studied using the uptake of the labeled non-metabolizable glucose analogue 2-DOG. Cells were washed three times with glucose-free PBS at room temperature. Sertoli cells were then incubated at $34^{\circ} \mathrm{C}$ in $0.5 \mathrm{ml}$ glucose-free PBS containing $\left[2,6-{ }^{3} \mathrm{H}\right]-2-$ DOG $(0.5 \mu \mathrm{Ci} / \mathrm{ml})$ for $30 \mathrm{~min}$. Unspecific uptake was determined in incubations performed in the presence of a 10 000-fold higher concentration of unlabeled 2-DOG. At the end of the incubation period, dishes were placed on ice and washed extensively with ice-cold PBS until no radioactivity was present in the washings. Cells were then dissolved with $0.5 \mathrm{M}$ sodium hydroxide and $0.4 \%$ sodium deoxycholate and counted in a liquid scintillation spectrophotometer. Parallel cultures receiving identical treatments to those performed before the glucose uptake assay were destined for DNA determinations. Results were expressed on a per microgram DNA basis.

\section{LDH activity measurement}

After incubation of Sertoli cells in the absence or presence of AICAR, culture medium was discarded and cells were disrupted by ultrasonic irradiation in $0.9 \%$ $\mathrm{NaCl}$ and centrifuged at $15800 \mathrm{~g}$ for $10 \mathrm{~min}$. The supernatant was used to measure LDH activity. Total LDH activity was determined by a routinely used spectrophotometric method (Randox Laboratories, Crumlin, UK). Results were expressed on a per microgram DNA basis.

\section{Lactate determination}

Lactate was measured by a standard method involving conversion of $\mathrm{NAD}^{+}$to $\mathrm{NADH}$ determined as the rate of increase of absorbance at $340 \mathrm{~nm}$. A commercial kit from Sigma-Aldrich was used. Results were expressed on a per microgram DNA basis.

\section{Other assays}

DNA content in Sertoli cell monolayers was determined by the method of Labarca \& Paigen (1980).

\section{Statistical analysis}

All experiments were run in triplicate and repeated three to four times. Results are expressed as means \pm s.D. 
One-way ANOVA with Tukey-Kramer post test was performed using GraphPad InStat version 3.00 for Windows 95 (GraphPad Software, San Diego, CA, USA). Probabilities $<0.05$ were considered as statistically significant.

\section{Results}

\section{Activation of AMPK stimulates lactate production in Sertoli cells}

In order to determine whether AMPK is present in Sertoli cells, western blot analysis for $\alpha$ AMPK-subunit was performed in Sertoli cell lysates and compared with that of muscle and testicular homogenates. Figure 1 shows that high levels of AMPK were present in Sertoli cells. The compound AICAR, a selective cell-permeable activator of AMPK, was utilized to study the participation of the enzyme in the regulation of Sertoli cell metabolism. Treatment of the cultures with $1 \mathrm{mM}$ AICAR for 1,2 , and $4 \mathrm{~h}$ resulted in an increase of phospho-Thr172-AMPK levels indicating activation of the enzyme (Fig. 2A). In addition, a dose-response curve in 2-h incubations with AICAR was observed (Fig. 2B).

The next set of experiments was performed in order to analyze a possible effect of AMPK activation on Sertoli cell lactate production. Figure 3A shows the effect of AICAR on Sertoli cells incubated for variable periods of time $(12,24$, and $48 \mathrm{~h})$ with a $1 \mathrm{mM}$ dose. Increments in lactate secretion, in all incubation periods tested, were observed. Figure 3B shows a dose-response increment in lactate production obtained in Sertoli cells incubated for $48 \mathrm{~h}$ with variable doses of $\operatorname{AICAR}(0 \cdot 3,0 \cdot 6$, and $1 \mathrm{mM})$.

\section{Different biochemical processes are implicated in the regulation of lactate production by AMPK activation}

\section{Glucose uptake and GLUTs expression}

As glucose availability for glycolysis is essential to lactate production, we decided to analyze whether AMPK
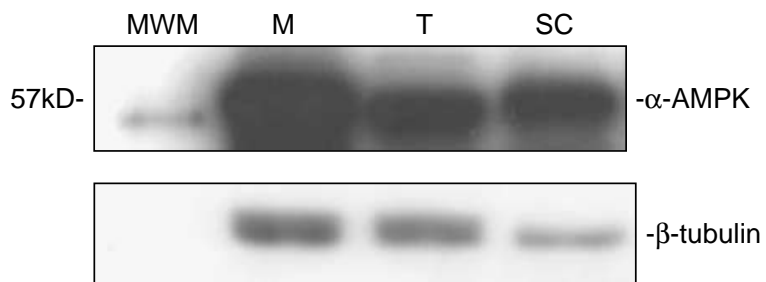

Figure 1 Expression of the $\alpha$-subunit of AMPK in Sertoli cells. Muscle (M) and testis (T) homogenates and Sertoli cells (SC) lysates were utilized for western blot analysis as described in Materials and methods. MWM shows the $57 \mathrm{kDa}$ band of a biotinylated protein marker. The $\alpha$-subunit of AMPK and $\beta$-tubulin were recognized with specific antibodies. activation modifies glucose uptake in Sertoli cells. Figure 4A shows the results obtained for 2-DOG uptake in cells stimulated with $1 \mathrm{mM}$ AICAR for variable periods of time $(1,2$, and $4 \mathrm{~h})$. A significant increase in glucose incorporation into the cell in 2- and 4-h incubation periods with the riboside was observed. Figure $4 \mathrm{~B}$ shows that treatment of Sertoli cell cultures with $0 \cdot 3,0 \cdot 6$, and $1 \mathrm{mM}$ AICAR for $2 \mathrm{~h}$ promoted dosedependent increments in 2-DOG incorporation.

Thereafter, experiments were performed to determine whether activation of AMPK was also able to regulate the levels of expression of GLUT1 and GLUT3. Figure 5A and B show respectively that AICAR increased GLUT1 and decreased GLUT3 mRNA levels in a time-dependent manner.

\section{$L D H$ activity and $L D H A$ expression}

In Sertoli cells, increments in lactate production have been correlated with an increase in LDH activity which is accompanied by an increase in LDH A mRNA levels in several experimental models (Nehar et al. 1997, 1998, Riera et al. 2001, 2002). To further investigate biochemical steps that may be involved in the increase of lactate production by AMPK activation, experiments were designed to study the effect of AICAR on LDH activity and LDH A mRNA levels.

Figure $6 \mathrm{~A}$ and $\mathrm{B}$ shows that AICAR did not promote time- or dose-dependent regulation of $\mathrm{LDH}$ activity. A slight decrease in LDH A mRNA levels in Sertoli cells treated for $48 \mathrm{~h}$ with $1 \mathrm{mM}$ AICAR was observed. (Fig. 6C).

\section{MCTs expression}

Finally, we analyzed a possible role of AMPK in the regulation of MCT1 and MCT4. Figure 7A shows that MCT1 and MCT4 are present in Sertoli cells and Fig. 7B and $\mathrm{C}$ shows that treatment of Sertoli cells for 12, 24, or $48 \mathrm{~h}$ with $1 \mathrm{mM}$ AICAR decreased MCT1 and increased MCT4 mRNA levels respectively.

\section{Discussion}

Carbohydrate metabolism in Sertoli cells presents some unique characteristics. Sertoli cells actively metabolize glucose but the majority of it is converted to lactate and is not oxidized via the citric acid cycle (Robinson \& Fritz 1981, Grootegoed et al. 1986). On the other hand, postmeiotic germ cells are unable to use glucose for their energetic metabolism and they do prefer lactate as an energy source (Jutte et al. 1981, Mita \& Hall 1982). These observations have led to the conclusion that one of the most important Sertoli cell nurse functions is to provide lactate for the production of energy in 
A
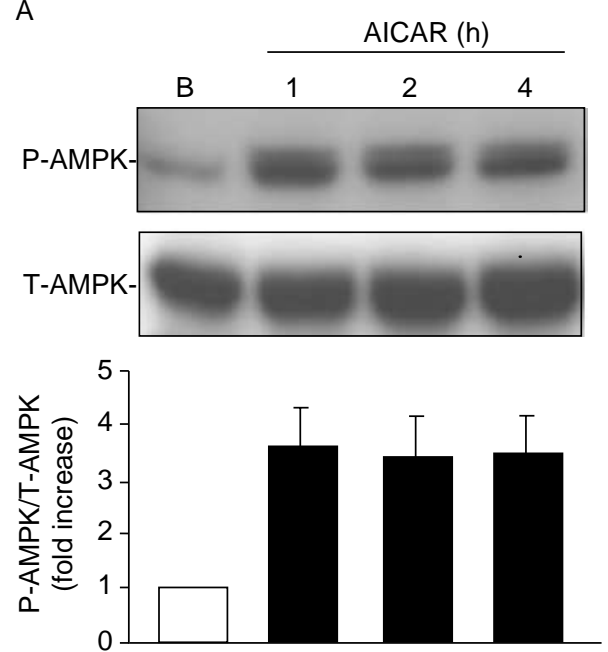
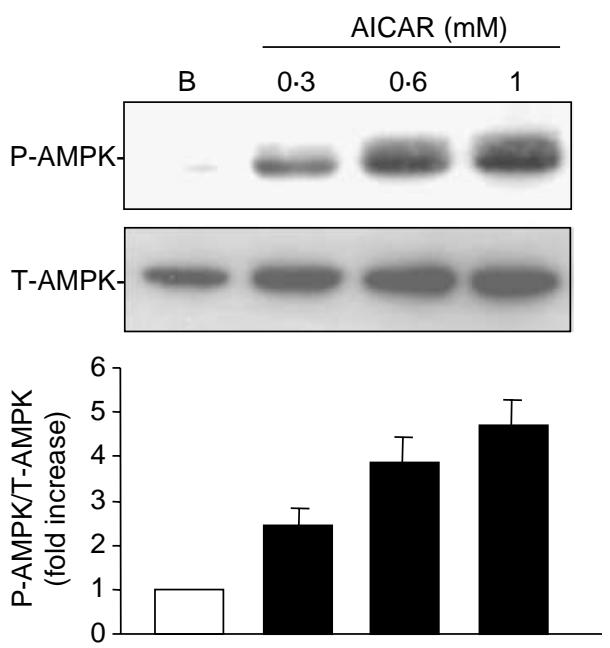

Figure 2 Effect of AICAR on P-AMPK levels in Sertoli cells. (A) Sertoli cells were incubated in the absence or presence of $1 \mathrm{mM}$ AICAR for variable periods of time $(1,2$, and $4 \mathrm{~h})$. (B) Sertoli cells were incubated for $2 \mathrm{~h}$ in the absence or presence of variable doses of AICAR (0.3, $0 \cdot 6$, and $1 \mathrm{mM}$ ). Cell extracts were prepared at the designated intervals and utilized for western blot analysis using antibodies specific for P-AMPK or T-AMPK. The upper panels show a representative experiment out of three. The lower panels show pooled data of three independent experiments indicating the fold variation in phosphorylation (ratio of P-AMPK to T-AMPK in each sample) relative to basal. Results are expressed as means \pm S.D.

spermatocytes and spermatids (Boussouar \& Benahmed 2004). In this way, the mechanisms that regulate lactate production in Sertoli cells are relevant in maintaining spermatogenesis and male fertility.

AMPK, a sensor of energy status of the cells, is a key enzyme in regulating glucose oxidation to obtain ATP. It has been shown that AMPK is present in the testis (Cheung et al. 2000). However, no reports are available for the presence of this enzyme specifically in Sertoli cells. The present study shows that in 20-day-old rats, when Sertoli cells in the testis are in a process of terminal differentiation, there are high levels of AMPK in these cells.

A

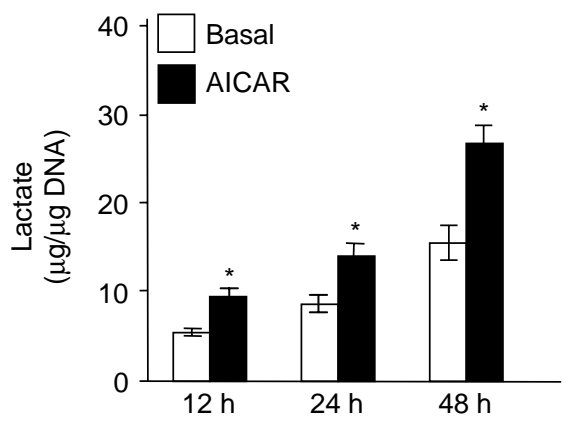

Stimulation of AMPK leads to metabolic changes responsible for obtaining maximal energy yield from glucose. In this context, AMPK activation by AICAR results in glucose oxidation and an increase in the activity of pyruvate dehydrogenase that favors the conversion of pyruvate in Acetyl-CoA in rat soleus muscle (Smith et al. 2005). In addition, Ceddia \& Sweeney (2004) showed that AMPK activation promotes an increase in glucose oxidation with a reduction in lactate production and Putman et al. (2003) showed increases in citrate synthase activity and decreases in LDH activity in skeletal muscle cells. Altogether, the latter reports are consistent with a decrease in lactate

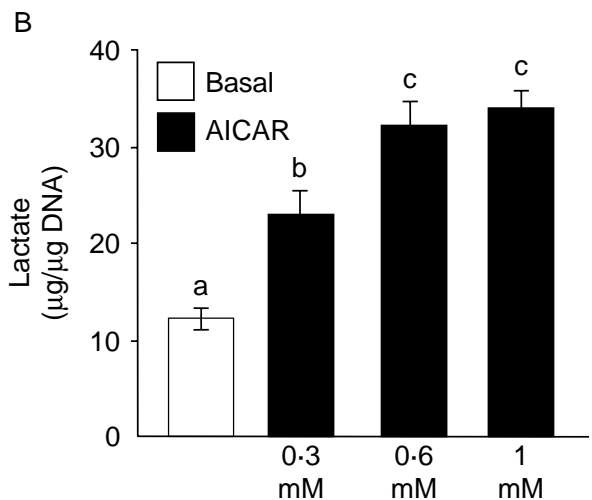

Figure 3 Effect of AICAR on lactate production in Sertoli cells. (A) Sertoli cells were incubated in the absence or presence of $1 \mathrm{mM}$ AICAR for variable periods of time $(12,24$, and $48 \mathrm{~h})$. (B) Sertoli cells were incubated in the absence or presence of variable doses of AICAR $(0 \cdot 3$, 0.6 , or $1 \mathrm{mM}$ ) for $48 \mathrm{~h}$. Lactate was determined in the conditioned media at the indicated times. Values are expressed as means \pm s.D. of triplicate incubations in one representative experiment out of three. ${ }^{\star} P<0.01$ versus basal. Different letters indicate statistically significant differences $(P<0 \cdot 01)$. 
A

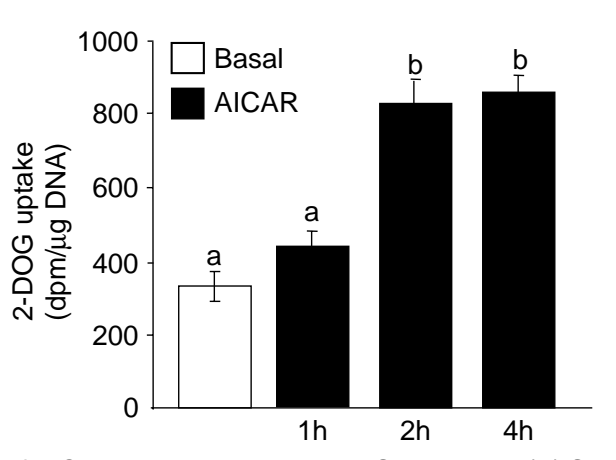

B

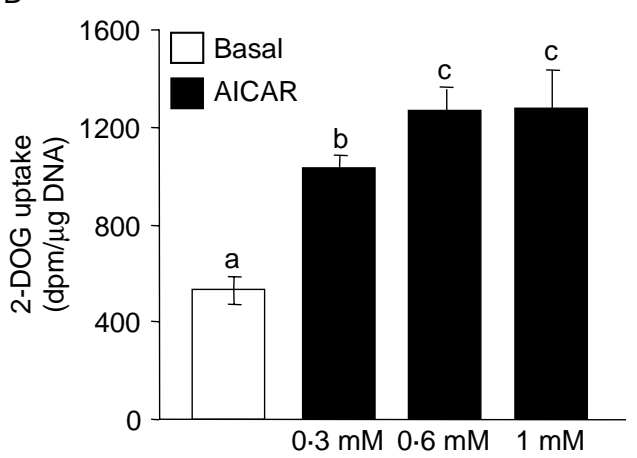

Figure 4 Effect of AICAR on glucose uptake in Sertoli cells. (A) Sertoli cells were incubated in the absence or presence of 1 mM AICAR for variable periods of time $(1,2$, and $4 \mathrm{~h})$. (B) Sertoli cells were incubated for $2 \mathrm{~h}$ in the absence or presence of variable doses of AICAR $(0 \cdot 3$, 0.6 , and $1 \mathrm{mM}$ ). Glucose uptake assay (2-DOG uptake) was performed after the corresponding incubation periods. Results represent means \pm s.D. of triplicate incubations in one representative experiment out of three. Different letters indicate statistically significant differences $(P<0 \cdot 01)$.

production in response to AMPK activation that is destined to increase energy yield in the mitochondria. The present study shows that in Sertoli cells, AMPK activation by AICAR promotes a dose- and timedependent increment in lactate secretion. These results suggest that under those conditions when there is an increase in the AMP:ATP ratio and in the activation of AMPK, Sertoli cells privilege lactate secretion in order to maintain the energy supply to germ cells. It is worth mentioning that knock-out male mice for LKB1 - the major upstream activator of the AMPK - are infertile (Sakamoto et al. 2005). Based on this observation, Sakamoto and collaborators have suggested a role for LKB1 in regulating spermatogenesis. Considering that our results show that AMPK activation leads to an increase in lactate production, it is tempting to speculate that one of the mechanisms underlying sterility may be related to the inability in the abovementioned animal model to fully activate AMPK in Sertoli cells and consequently to produce sufficient amounts of lactate to maintain germ cell development.

Several biochemical mechanisms may contribute to an increase in Sertoli cell lactate secretion. Glucose transport mediated by GLUTs - the rate-limiting step for glucose metabolism - and LDH activities play important roles respectively, at the beginning of the process, providing the substrate, and at the end of the process, interconverting pyruvate and lactate. In addition, the modulation of lactate release from Sertoli cells, regulating the expression of those MCTs
A
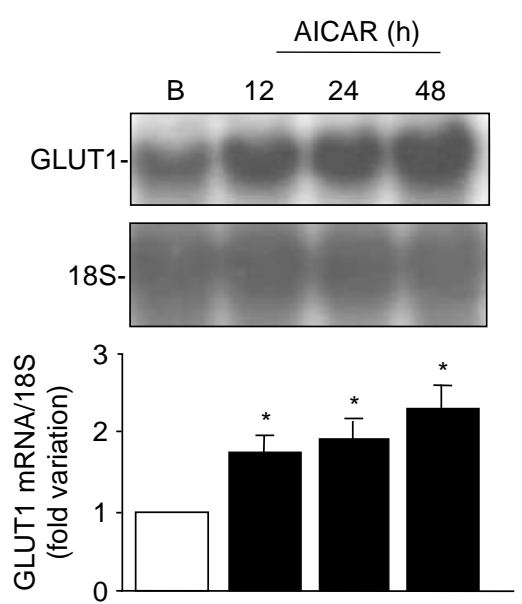

B

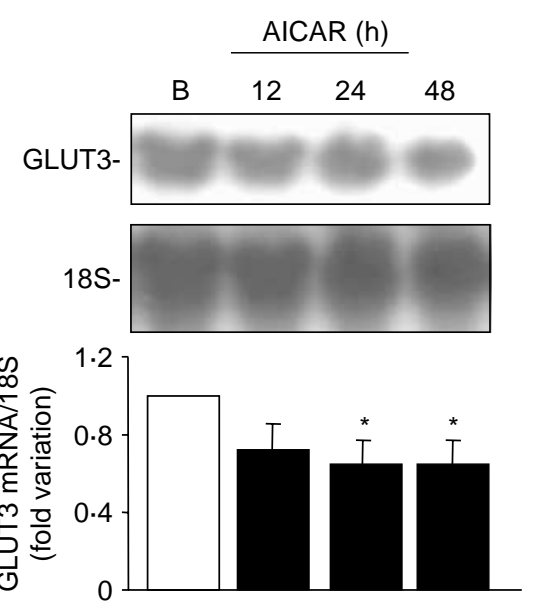

Figure 5 Effect of AICAR on GLUT1 and GLUT3 mRNA levels in Sertoli cells. Sertoli cells were incubated for variable periods of time $(12,24$, and $48 \mathrm{~h}$ ) with $1 \mathrm{mM}$ AICAR. Total cellular RNAs were then extracted and northern blotting analysis was performed using $20 \mu \mathrm{g}$ RNA per lane. Membranes were hybridized with labeled cDNA probes for GLUT1 (A) and GLUT3 (B). The upper panels show a representative experiment out of three. The lower panels show pooled data of three independent experiments performed indicating the fold variation in mRNA levels (ratio of GLUT1 mRNA to $18 \mathrm{~S}$ and of GLUT3 mRNA to $18 \mathrm{~S}$ in each sample) relative to basal. Results are expressed as means \pm s.D., ${ }^{*} P<0.05$ versus basal. 
A

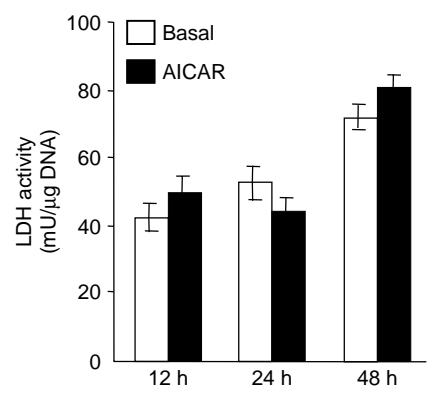

B

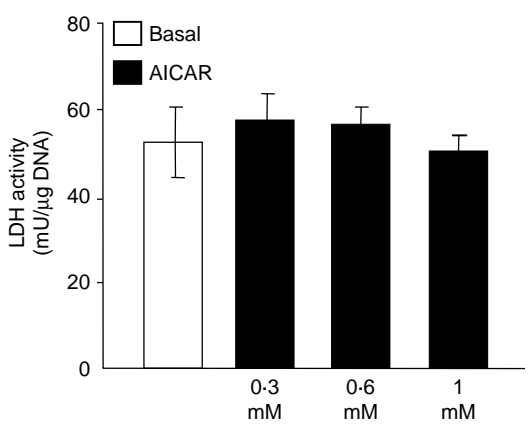

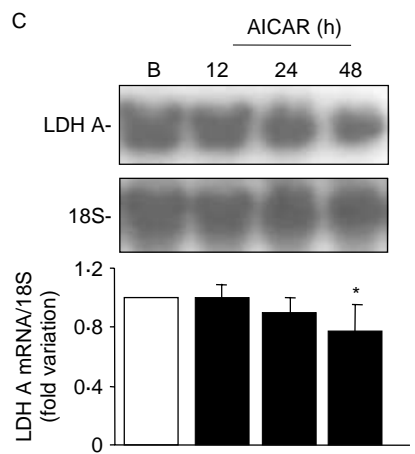

Figure 6 Effect of AICAR on LDH activity and LDH A mRNA levels in Sertoli cells. (A) Sertoli cells were incubated in the absence or presence of $1 \mathrm{mM}$ AICAR for variable periods of time $(12,24$, and $48 \mathrm{~h}$ ). (B) Sertoli cells were incubated for $48 \mathrm{~h}$ in the absence or presence of variable doses of $\operatorname{AICAR}(0.3,0.6$ and $1 \mathrm{mM})$. LDH activity was determined in the cellular monolayer. Results represent means \pm s.D. of triplicate incubations in one representative experiment out of three. (C) Sertoli cells were incubated for variable periods of time $(12,24$, and $48 \mathrm{~h})$ with $1 \mathrm{mM}$ AICAR. Total cellular RNAs were then extracted and northern blotting analysis was performed using $20 \mu \mathrm{g}$ total RNA per lane. Membranes were hybridized with labeled cDNA probes for LDH A and 18S. The upper panel shows a representative experiment out of four. The lower panel shows pooled data of four independent experiments indicating the fold variation in mRNA levels (ratio of LDH A mRNA to $18 \mathrm{~S}$ in each sample) relative to basal. Results are expressed as means \pm S.D., ${ }^{\star} P<0.05$ versus basal.

responsible for lactate export, may also contribute to improve lactate supply to germ cells.

Previous reports have shown an increase in glucose uptake following AMPK activation in a variety of tissues (Xi et al. 2001, Chen et al. 2002, Fryer et al. 2002, Lemieux et al. 2003, Pelletier et al. 2005). The present study shows that AMPK activation by AICAR increases glucose transport in rat Sertoli cells as well. In Sertoli cells, glucose transporters so far described include GLUT1, GLUT3 and GLUT8 (Ulisse et al. 1992, Kokk et al. 2004, Carosa et al. 2005). Glucose transport in Sertoli cells is probably mediated by the glucose transporters GLUT1 and GLUT3. Even though GLUT8 is present in rat Sertoli cells, this carrier protein is not present at the plasma membrane and probably is not involved in glucose transport from the extra cellular milieu.

Many of the known short-term effects of AMPK activation can be explained by direct phosphorylation and regulation of a variety of substrates (Hardie \& Hawley 2001). However, long-term activation of the kinase has also effects on the pattern of gene expression in a cell (Leclerc et al. 2002, Leff 2003). Protein expression, as a whole, is downregulated following AMPK activation. Yet, some proteins, which are essential for metabolic adaptation, will bypass the condition of energy saving associated with the activation of this kinase and will increase their expression (Hardie \& Hawley 2001). In relation to the latter assumption, we have observed that long-term activation of AMPK in rat Sertoli cells increases GLUT1 expression suggesting that this protein is essential for Sertoli cell functioning. The close relationship between AMPK and GLUT1 expression has been previously documented in skeletal muscle cells transfected with a constitutively active mutant form of the catalytic $\alpha$-subunit of AMPK and in DU145 prostate carcinoma cells stimulated with AICAR (Fryer et al. 2002, Yun et al. 2005). On the other hand, the decrease in GLUT3 mRNA levels following long-term activation of AMPK can be readily explained by the general inhibitory effect of AMPK activation on anabolic processes (Corton et al. 1994).

As for LDH isoenzyme system, Long et al. (2005) have demonstrated a role of AMPK in the expression of LDH-B subunit in white skeletal muscle cells in mice. On the other hand, Putman et al. (2003) have demonstrated that the long-term stimulation with AICAR reduces total LDH activity in skeletal muscle cells. The present study shows that in Sertoli cells, 
A
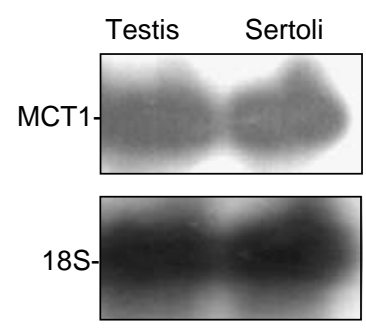

B
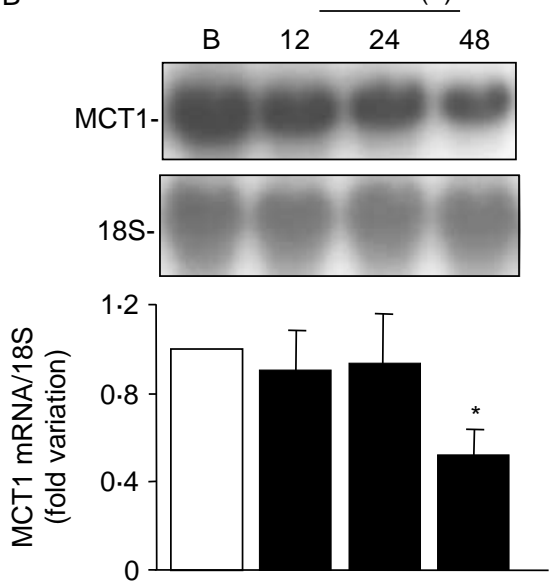
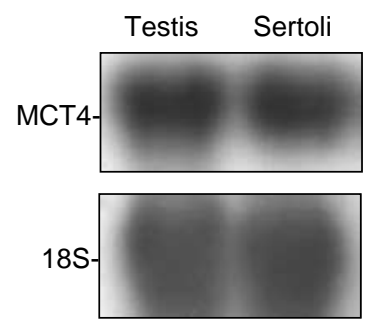

C

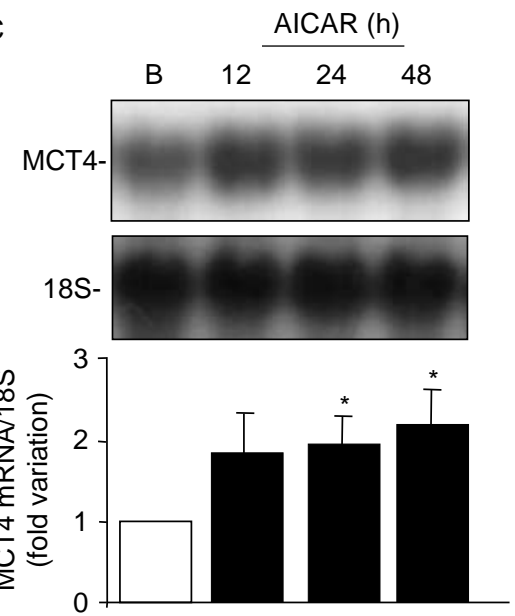

Figure 7 Effect of AICAR on MCT1 and MCT4 mRNA levels in Sertoli cells. (A) Whole testis and Sertoli cell RNA were prepared and utilized for northern blotting analysis using $20 \mu \mathrm{g}$ RNA per lane. Membranes were hybridized with labeled cDNA probes for MCT1, MCT4 and $18 \mathrm{~S}$. Sertoli cells were incubated for variable periods of time $(12,24$ and $48 \mathrm{~h}$ ) with $1 \mathrm{mM}$ AICAR. Total cellular RNAs were then extracted and northern blotting analysis was performed using $20 \mu \mathrm{g}$ total RNA per lane. Membranes were hybridized with labeled cDNA probes for MCT1 (B) and MCT4 (C). The upper panels show a representative experiment out of three. The lower panels show pooled data of three independent experiments indicating the fold variation in mRNA levels (ratio of MCT1 mRNA to 18S and of MCT4 mRNA to 18S in each sample) relative to basal. Results are expressed as means \pm s.D., ${ }^{\star} P<0.05$ versus basal.

different from what Putman and collaborators observed in skeletal muscle cells, LDH activity is maintained after the long-term incubations with AICAR. Although a slight decrease in LDHA mRNA levels was observed in 48-h incubations, this decrease was not evident in total LDH activity. This sustained LDH activity in Sertoli cells may be the result of cell adaptation to ensure a continuous lactate offer to meiotic germ cells.

Finally, regulation of lactate exit from Sertoli cells may be also a mechanism involved in lactate supply to germ cells. The transport of lactate across the plasma membrane is mediated by a family of proton-linked MCTs (Halestrap \& Price 1999). In the testis, the study of MCTs expression has been mainly analyzed in spermatogenic cells. RT-PCR, in situ mRNA hybridization, and immunocyto- and immunohistochemistry data show that pachytene spermatocytes express mainly MCT1 and MCT4 isoforms, while round spermatides also show expression of the MCT2 isoform (Goddard et al. 2003, Brauchi et al. 2005). We have looked in Sertoli cells for those MCTs that are expressed in the majority of the cells such as MCT1, and for those that are strongly expressed in glycolytic cells, which must export large amounts of lactate, such as MCT4 (Juel \& Halestrap 1999, Dimmer et al. 2000). We have confirmed that MCT1 and MCT4 are expressed in testicular tissue and in addition we have demonstrated that these transporters are expressed in Sertoli cells. As for the regulation of these transporters by AMPK activation, we have observed that while MCT1 mRNA levels are downregulated by AICAR treatment, MCT4 mRNA levels are upregulated. It has been postulated that MCT1 has a role in lactate import from the extracellular milieu. On the other hand, MCT4 which has a much lower affinity for lactate than MCT1 has been proposed to serve as lactate exporter. The manner in which both transporters are regulated in Sertoli cells by long-term AMPK activation may reflect a situation of increased lactate export and decreased lactate recapture from the extracellular milieu leading to adequate lactate levels at the disposal of germ cells.

In conclusion, the results presented herein show that AMPK is present in Sertoli cells and that its activation by AICAR increases lactate production as a result, at least 
in part, of a) an increase in glucose uptake, b) an increase in GLUT1 expression, and c) a decrease in MCT1 and an increase in MCT4 levels. Altogether, these results suggest an important role of AMPK in modulating the nutritional function of Sertoli cells.

\section{Acknowledgements}

The authors express their gratitude to Dr Birnbaum (Philadelphia, USA) for providing GLUT1 cDNA, to Dr Nagamatsu (Tokyo, Japan) for providing GLUT3 cDNA, to Dr Jungmann (Chicago, USA) for providing LDH A cDNA, and to Dr Bröer (Canberra, Australia) for providing MCT-1 and MCT-4 cDNA. The technical help of Mercedes Astarloa and Oscar Rodríguez is gratefully acknowledged. The work was supported by grants from the Agencia Nacional de Promoción Científica y Tecnológica (PICT 08681; PICT 25365) and CONICET (PIP 5479), Argentina. SBM and SBC are established investigators of CONICET. MNG and MFR are recipients of a CONICET fellowship. The authors declare that there is no conflict of interest that would prejudice the impartiality of this scientific work.

\section{References}

Boussouar F \& Benahmed M 2004 Lactate and energy metabolism in male germ cells. TRENDS in Endocrinology and Metabolism 15 345350 .

Brauchi S, Rauch MC, Alfaro IE, Cea C, Concha Benos DJ II \& Reyes JG 2005 Kinetics, molecular basis, and differentiation of L-lactate transport in spermatogenic cells. American Journal of Physiology. Cell Physiology 288 523-534.

Carosa E, Radico C, Giansante N, Rossi S, D'Adamo F, Di Stasi SM, Lenzi A \& Jannini EA 2005 Ontogenetic profile and thyroid hormone regulation of type- 1 and type- 8 glucose transporters in rat Sertoli cells. International Journal of Andrology 28 99-106.

Ceddia RB \& Sweeney G 2004 Creatine supplementation increases glucose oxidation and AMPK phosphorylation and reduces lactate production in L6 rat skeletal muscle cells. Journal of Physiology $\mathbf{5 5 5}$ 409-421.

Chen HC, Bandyopadhyay G, Sajan MP, Kanoh Y, Standaert M, Farese RV Jr \& Farese RV 2002 Activation of the ERK pathway and atypical protein kinase $\mathrm{C}$ isoforms in exercise- and aminoimidazole-4carboxamide-1- $\beta$-D-riboside (AICAR)-stimulated glucose transport. Journal of Biological Chemistry 277 23554-23562.

Cheung PC, Salt IP, Davies SP, Hardie DG \& Carling D 2000 Characterization of AMP-activated protein kinase gamma-subunit isoforms and their role in AMP binding. Biochemical Journal 346 659-669.

Chomczynski P \& Sacchi N 1987 Single-step method of RNA isolation by acid guanidinium thiocyanate-phenol-chlorofom extraction. Analytical Biochemistry 162 156-159.

Corton JM, Gillespie JG \& Hardie DG 1994 Role of the AMP-activated protein kinase in the cellular stress response. Current Biology 4 315-324.

Corton JM, Gillespie JG, Hawley SA \& Hardie DG 1995 5-aminoimidazole-4-carboxamide ribonucleoside. A specific method for activating AMP-activated protein kinase in intact cells? European Journal of Biochemistry 229 558-565.
Courtens JL \& Ploen L 1999 Improvement of spermatogenesis in adult cryptorchid rat testis by intratesticular infusion of lactate. Biology of Reproduction 61 154-161.

Dimmer KS, Friedrich B, Lang F, Deitmer JW \& Broer S 2000 The lowaffinity monocarboxylate transporter MCT4 is adapted to the export of lactate in highly glycolytic cells. Biochemical Journal $\mathbf{3 5 0}$ 219-227.

Fryer LG, Foufelle F, Barnes K, Baldwin SA, Woods A \& Carling D 2002 Characterization of the role of the AMP-activated protein kinase in the stimulation of glucose transport in skeletal muscle cells. Biochemical Journal 363 167-174.

Gaidhu MP, Fediuc S \& Ceddia RB 2006 5-Aminoimidazole-4carboxamide-1- $\beta$-D-ribofuranoside-induced AMP-activated protein kinase phosphorylation inhibits basal and insulin-stimulated glucose uptake, lipid synthesis, and fatty acid oxidation in isolated rat adipocytes. Journal of Biological Chemistry 281 25956-25964.

Goddard I, Florin A, Mauduit C, Tabone E, Contard P, Bars R, Chuzel F \& Benahmed M 2003 Alteration of lactate production and transport in the adult rat testis exposed in utero to flutamide. Molecular and Cellular Endocrinology 206 137-146.

Grootegoed JA, Oonk RB, Jansen R \& van der Molen HJ 1986 Metabolism of radiolabelled energy-yielding substrates by rat Sertoli cells. Journal of Reproduction and Fertility 77 109-118.

Halestrap AP \& Price NT 1999 The proton-linked monocarboxylate transporter (MCT) family: structure, function and regulation. Biochemical Journal 343 281-299.

Hardie DG 2003 Minireview: the AMP-activated protein kinase cascade: the key sensor of cellular energy status. Endocrinology 144 5179-5183.

Hardie DG 2004 The AMP-activated protein kinase pathway-new players upstream and downstream. Journal of Cell Science 117 5479-5487.

Hardie DG 2005 New roles for the LKB1 $\rightarrow$ AMPK pathway. Current Opinion in Cell Biology 17 167-173.

Hardie DG \& Hawley SA 2001 AMP-activated protein kinase: the energy charge hypothesis revisited. BioEssays 23 1112-1119.

Hardie DG \& Pan DA 2002 Regulation of fatty acid synthesis and oxidation by the AMP-activated protein kinase. Biochemical Society Transactions 30 1064-1070.

Hardie DG \& Sakamoto K 2006 AMPK: a key sensor of fuel and energy status in skeletal muscle. Physiology 21 48-60.

Juel C \& Halestrap AP 1999 Lactate transport in skeletal muscle - role and regulation of the monocarboxylate transporter. Journal of Physiology 517 633-642.

Jutte NH, Grootegoed JA, Rommerts FF \& van der Molen HJ 1981 Exogenous lactate is essential for metabolic activities in isolated rat spermatocytes and spermatids. Journal of Reproduction and Fertility 62 399-405.

Kokk K, Verajankorva E, Wu XK, Tapfer H, Poldoja E \& Pollanen P 2004 Immunohistochemical detection of glucose transporters class I subfamily in the mouse, rat and human testis. Medicina $\mathbf{4 0}$ $156-160$.

Labarca C \& Paigen K 1980 A simple, rapid and sensitive DNA assay procedure. Analytical Biochemistry 102 344-352.

Laemmli UK 1970 Cleavage of structural proteins during the assembly of the head of bacteriophage T4. Nature 277 680-685.

Leclerc I, Viollet B, da Silva Xavier G, Kahn A \& Rutter GA 2002 Role of AMP-activated protein kinase in the regulation of gene transcription. Biochemical Society Transactions 30 307-311.

Leff T 2003 AMP-activated protein kinase regulates gene expression by direct phosphorylation of nuclear proteins. Biochemical Society Transactions 31 224-227.

Lemieux K, Konrad D, Klip A \& Marette A 2003 The AMP-activated protein kinase activator AICAR does not induce GLUT4 translocation to transverse tubules but stimulates glucose uptake and p38 mitogen-activated protein kinases alpha and beta in skeletal muscle. FASEB Journal 17 1658-1665. 
Long YC, Barnes BR, Mahlapuu M, Steiler TL, Martinsson S, Leng Y, Wallberg-Henriksson H, Andersson L \& Zierath JR 2005 Role of AMP-activated protein kinase in the coordinated expression of genes controlling glucose and lipid metabolism in mouse white skeletal muscle. Diabetologia 48 2354-2364.

Lowry OH, Rosebrough NJ, Farr AL \& Randall RJ 1951 Protein measurement with the folin phenol reagent. Journal of Biological Chemistry 193 265-275.

Meroni SB, Riera MF, Pellizzari EH \& Cigorraga SB 2002 Regulation of rat Sertoli cell function by FSH: possible role of phosphatidylinositol 3-kinase/protein kinase B pathway. Journal of Endocrinology 174 195-204.

Mita M \& Hall PF 1982 Metabolism of round spermatids from rats: lactate as the preferred substrate. Biology of Reproduction 26 445-455.

Nehar D, Mauduit C, Boussouar F \& Benahmed M 1997 Tumor necrosis factor-alpha-stimulated lactate production is linked to lactate dehydrogenase A expression and activity increase in porcine cultured Sertoli cells. Endocrinology 138 1964-1971.

Nehar D, Mauduit C, Boussouar F \& Benahmed M 1998 Interleukin lalpha stimulates lactate dehydrogenase A expression and lactate production in cultured porcine Sertoli cells. Biology of Reproduction 59 1425-1432.

Pelletier A, Joly E, Prentki M \& Coderre L 2005 Adenosine 5 '-monophosphate-activated protein kinase and p38 mitogenactivated protein kinase participate in the stimulation of glucose uptake by dinitrophenol in adult cardiomyocytes. Endocrinology 146 2285-2294.

Putman CT, Kiricsi M, PearceyJ, MacLean IM, Bamford JA, Murdoch GK, Dixon WT \& Pette D 2003 AMPK activation increases uncoupling protein-3 expression and mitochondrial enzyme activities in rat muscle without fibre type transitions. Journal of Physiology 551 169-178. Riera MF, Meroni SB, Gomez GE, Schteingart HF, Pellizzari EH \& Cigorraga SB 2001 Regulation of lactate production by FSH, IL1 $\beta$ and TNF $\alpha$ in rat Sertoli cells. General and Comparative Endocrinology 122 88-97.
Riera MF, Meroni SB, Schteingart HF, Pellizzari EH \& Cigorraga SB 2002 Regulation of lactate production and glucose transport as well as of glucose transporter 1 and lactate dehydrogenase A mRNA levels by basic fibroblast growth factor in rat Sertoli cells. Journal of Endocrinology 173 335-343.

Robinson R \& Fritz IB 1981 Metabolism of glucose by Sertoli cells in culture. Biology of Reproduction 24 1032-1041.

Sakamoto K, McCarthy A, Smith D, Green KA, Hardie DG, Ashworth A \& Alessi DR 2005 Deficiency of LKB1 in skeletal muscle prevents AMPK activation and glucose uptake during contraction. EMBO Journal 24 1810-1820.

Smith AC, Bruce CR \& Dyck DJ 2005 AMP kinase activation with AICAR simultaneously increases fatty acid and glucose oxidation in resting rat soleus muscle. Journal of Physiology 565 537-546.

Ulisse S, Jannini EA, Pepe M, De Matteis S \& D'Armiento M 1992 Thyroid hormone stimulates glucose transport and GLUT1 mRNA in rat Sertoli cells. Molecular and Cellular Endocrinology 87 131-137.

Xi X, Han J \& Zhang JZ 2001 Stimulation of glucose transport by AMP-activated protein kinase via activation of p38 mitogenactivated protein kinase. Journal of Biological Chemistry 276 41029-41034.

Yun H, Lee M, Kim SS \& Ha J 2005 Glucose deprivation increases mRNA stability of vascular endothelial growth factor through activation of AMP-activated protein kinase in DU145 prostate carcinoma. Journal of Biological Chemistry 280 9963-9972.

Received in final form 6 July 2007

Accepted 7 August 2007

Made available online as an Accepted Preprint

10 August 2007 